\title{
PENERAPAN MODEL PEMBELAJARAN KOOPERATIF TIPE NUMBERED HEADS TOGETHER (NHT) DENGAN MEDIA KARTU INDEKS DALAM MENINGKATKAN HASIL BELAJAR IPA TERPADU SISWA KELAS VIII SMP NEGERI 3 SABBANGPARU
}

\author{
Ahmad Yani \\ MIPA, STKIP Puangrimaggalatung Sengkang \\ email: ahyan_yani@yahoo.com
}

\section{ABSTRAK}

Penelitian ini merupakan penelitian tindakan kelas (Classroom Action Research) yang bertujuan untuk meningkatkan hasil belajar siswa melalui penerapan model pembelajaran kooperatif tipe Numbered Heads Together (NHT) dengan media kartu indeks pada pokok bahasan Sistem Peredaran Darah. Subjek penelitian ini adalah siswa SMP Negeri 3Sabbangparu kelas VIII yang berjumlah 25orang, terdiri atas 11 siswa laki-laki dan 14 siswa perempuan tahun pelajaran 2012/2013. Penelitian ini dilaksanakan dalam 2 siklus yang terdiri dari empat komponen, yaitu: perencanaan tindakan, pelaksanaan tindakan, observasi dan refleksi.Pengumpulan data dilakukan dengan cara observasi dan tes setiap akhir siklus. Data hasil belajar dianalisis secara kuantitatif. Hasil penelitian ini menunjukkan bahwasebelum penelitian skor rata-rata hasil belajar siswa 62.93 masih tergolong sedang, pada siklus I skor rata-rata hasilbelajar siswa mengalami peningkatan menjadi 64.93dari skor ideal yang mungkin dicapai 100. Skor hasil belajar ini tergolong kategori sedang.Pada siklus II skor rata-rata hasil belajar siswa 75.73 dari skor ideal yang mungkin dicapai 100 dan berada dalam kategori tinggi.Sedangkan persentase ketuntasan klasikal pada siklus I sebesar $68 \%$ mengalami peningkatan pada siklus II menjadi 100\%.Dari hasil analisis di atas dapat disimpulkan bahwa dengan penerapan model pembelajaran kooperatif tipe Numbered Heads Together dengan media kartu indeks dapat meningkatkan hasil belajar IPA Terpadu siswa kelas VIII pada SMP Negeri 3 Sabbangparu Kabupaten Wajo.

\section{Kata Kunci : Model pembelajaran kooperatif, Media kartu indeks, Hasil belajar}

\section{PENDAHULUAN}

\section{Tantangan dalam dunia} pendidikan saat ini adalah bagaimana menyiapkan kualitas sumber daya manusia yang mampu bersaing dalam era global yang menuntut keterampilan serta kreatifitas tinggi. Oleh karena itu, pendidikan memerlukan perhatian yang khusus dari segi mutu atau kualitasnya. Banyak hal yang telah diupayakan pemerintah agar mutu pendidikan di Indonesia menjadi lebih baik yaitu dengan adanya pembaharuan pendidikan. Ada tiga komponen yang perlu diperhatikan dalam pembaharuan pendidikan yaitu pembaharuan kurikulum, peningkatan kualitas pembelajaran, dan efektifitas model pembelajaran.

Proses pembelajaran di kelas memiliki peran yang sangat penting dalam upaya pencapaian tujuan pembelajaran. Proses belajar mengajar merupakan inti dalam kegiatan pendidikan yang melibatkan komponen guru dan peserta didik. Guru hendaknya lebih kreatif dalam memilih model-model pembelajaran yang 
sesuai dengan keadaan serta kondisi lingkungan di mana dia mengajar. Pemilihan dan penentuan model pembelajaran yang sesuai dengan karakter;istik materi yang diajarkan diharapkan akan memudahkan siswa dalam memahami materi tersebut.

Selama ini siswa selalu terkondisikan untuk menerima informasi apa adanya, sehingga siswa cenderung pasif dan menunggu diberi informasi tanpa berusaha menemukan informasi tersebut. Hal itu menyebabkan siswa hanya mampu untuk menghapal tanpa memahami materi yang telah diterimanya. Oleh karena itu, diperlukan sebuah model pembelajaran baru yang menekankan keaktifan siswa. Salah satu model pembelajaran yang lebih menekankan pada keaktifan siswa adalah model pembelajaran kooperatif.

Pembelajaran kooperatif dapat mendukung tercapainya peningkatan partisipasi siswa, hal ini disebabkan karena pembelajaran kooperatif bertumpu pada kelompok kecil dan siswa terlibat secara aktif dalam proses berfikir pada kegiatan-kegiatan belajar. Dengan demikian diperlukan suatu model pembelajaran yang sistematik, yang dapat mendorong siswa agar memiliki rasa tanggungjawab untuk menguasai materi, memicu siswa untuk menjadi lebih aktif, dan juga dalam penyajian pelajaran mampu membangkitkan semangat, gairah dan motivasi siswa.

Namun kenyataan menunjukkan bahwa model pembelajaran yang digunakan sebagian besar masih bersifat konvensional yang cenderung bersifat searah, artinya guru memberikan informasi, ide atau gagasan kemudian siswa menerima pelajaran yang diberikan. Model pembelajaran yang demikian kurang melibatkan siswa secara aktif.

Berdasarkan hasil observasi dan wawancara peneliti dengan guru IPA TERPADU SMP Negeri 3 Sabbangparu Kabupaten Wajo, tentang pembelajaran yang biasa dilaksanakan di sekolah tersebut menunjukkan bahwa kurangnya media pembelajaran serta penerapan metode pembelajaran terbaru, dan metode yang digunakan masih bersifat konvensional mengakibatkan kegiatan belajar mengajar tidak efektif. Oleh karena itu perlu dikembangkan suatu strategi pembelajaran yang dapat melibatkan siswa secara aktif, sehingga dapat meningkatkan hasil belajar siswa.

Melihat kenyataan tersebut, peneliti berinisiatif mengadakan penelitian dengan menerapkan salah satu model pembelajaran kooperatif yaitu, model pembelajaran kooperatif tipe Numbered Heads Together (NHT) atau penomoran berfikir bersama yang dikembangkan oleh Spencer Keangen (Lie, 2008). Dimana model pembelajaran kooperatif tipe NHT 
belum pernah diterapkan di sekolah tersebut.

Selain itu, penerapan model ini juga dikombinasikan dengan penggunaan media berupa kartu indeks karena model pembelajaran juga harus didukung dengan adanya media pembelajaran yang dapat meningkatkan motivasi siswa terhadap materi yang akan diajarkan oleh guru. Kartu indeks merupakan media visual yang berisi pesan, informasi, ataupun konsep dalam bentuk gambar ataupun pernyataan yang berkaitan dengan materi yang diajarkan. Kartu indeks dapat membangkitkan motivasi dan rangsangan kegiatan belajar, membantu keefektifan proses pembelajaran, menarik dan mengarahkan perhatian siswa untuk berkonsentrasi kepada isi pelajaran yang berkaitan dengan makna visual yang ditampilkan, memperlancar pencapaian tujuan untuk memahami dan mengingat informasi atau pesan, pembelajaran menjadi lebih menarik, membawa kesegaran dan variasi baru bagi pengalaman belajar siswa sehingga siswa tidak bosan, dapat mengatasi keterbatasan indra, ruang, dan waktu, meningkatkan pencurahan waktu pada tugas, rasa harga diri,menjadi lebih tinggi, pemahaman yang lebih mendalam, meningkatkan kebaikan budi, kepekaan, toleransi, dan hasil belajar bisa lebih tinggi.

Berdasarkan pemaparan di atas, maka peneliti tertarik melakukan penelitian dengan judul "Penerapan Model Pembelajaran Kooperatif Tipe Numbered Heads Together dengan Media Kartu Indeks dalam Meningkatkan Hasil Belajar IPA Terpadu Siswa Kelas VIII SMP Negeri 3 Sabbangparu".

\section{TINJAUAN PUSTAKA}

\section{A. Model Pembelajaran Kooperatif}

Model pembelajaran adalah suatu perencanaan atau suatu pola yang digunakan sebagai pedoman dalam merencanakan pembelajaran di kelas dan untuk menentukan perangkat-perangkat pembelajaran serta mengarahkan kita dalam mendesain pembelajaran untuk membantu peserta didik mencapai tujuan pembelajaran Joyce (1992) dalam Trianto (2007).

Menurut Ibrahim $d k k$. (2000), keunggulan yang diperoleh dalam pembelajaran kooperatif diantaranya : a). Siswa tidak terlalu menggantungkan pada guru, akan tetapi dapat menambah kepercayaan, kemampuan berpikir sendiri, menemukan informasi dari berbagai sumber, dan belajar dari siswa yang lain, b). Mengembangkan kemampuan mengungkapkan ide atau gagasan dengan kata-kata verbal dan membandingkannya dengan ide-ide orang lain, c). Membantu anak untuk respek pada orang lain dan menyadari akan segala keterbatasannya, d). Membantu 
memberdayakan setiap siswa untuk lebih bertanggung jawab dalam belajar, e). Suatu strategi yang cukup ampuh untuk meningkatkan prestasi sekaligus kemampuan sosial, f). Mengembangkan kemampuan siswa untuk menguji ide dan pemahamannya sendiri, menerima umpan balik, g). Meningkatkan motivasi dan memberikan rangsangan untuk berpikir.

\section{B. Pembelajaran Kooperatif Tipe}

"Number Heads Together (NHT)"

Model pembelajaran kooperatif tipe Numbered Heads Together (NHT), sebagaimana yang dikemukakan oleh Ibrahim dkk. (2000) dalam (Nurwahyuni) adalah suatu pendekatan yang dikembangkan oleh Spencer Kangen untuk melibatkan lebih banyak siswa dalam menelaah materi yang tercakup dalam suatu pelajaran dan mengecek pemahaman mereka terhadap isi pelajaran tersebut. Teknik ini memberikan kesempatan kepada siswa untuk saling memberikan ide-ide dan mempertimbangkan jawaban yang paling tepat. Selain itu teknik ini juga mendorong siswa atau meningkatkan semangat kerja mereka.

Trianto

$$
\text { (2007), }
$$

menerapkan

langkah-langkah pembelajaran kooperatif tipe Numbered Heads Together (NHT) sebagai berikut:

Langkah 1: Penomoran(Numbering).

Guru membagi siswa kedalam kelompok beranggotakan3-

5orangdankepada setiap anggota kelompok diberi nomor antara $1-5$.

Langkah 2: Mengajukan pertanyaan (Questioning). Guru mengajukan sebuah pertanyaan kepada siswa. Pertanyaan dapat bervariasi. Pertanyaan dapat amat spesifik dan dalam bentuk kalimat tanya.

Langkah $\quad 3$ : Berpikir bersama (Heads together). Siswa menyatukan pendapatnya terhadap jawaban dan menyakinkan setiap anggota dalam timnya mengetahui jawaban itu.

4: Menjawab (Answering). Guru memanggil suatu nomor tertentu kemudian siswa yang nomornya sesuai, mengacungkan tangannya dan mencoba untuk menjawab pertanyaan seluruh kelas.

\section{Hasil Belajar}

Menurut Sujana, (1991) dalam Iskandar, (2009) hasil belajar adalah suatu akibat dari proses belajar dengan menggunakan alat pengukuran yaitu berupa tes yang disusun secara terencana, baik, tes tertulis, tes lisan maupun tes 
perbuatan. Hasil belajar seringkali diasumsikan sebagai cermin kualitas suatu sekolah. Dengan hasil belajar yang diperoleh, guru akan mengetahui apakah metode serta media yang digunakan sudah tepat atau belum. Jika sebagian besar siswa memperoleh angka jelek pada penelitian yang diadakan, mungkin hal ini disebabkan oleh pendekatan/metode dan media yang digunakan kurang tepat. Apabila demikian halnya, maka guru harus mawas diri dan mencoba mencari metode dan media lain dalam mengajar (Arikunto, 2005).

Menurut Sabri (2010), faktorfaktor yang mempengaruhi belajar banyak jenisnya, tetapi dapat digolongkan menjadi dua golongan saja, yaitu faktor intern dan faktor ekstern. Faktor intern adalah faktor yang ada dalam diri individu yang sedang belajar, antara lain: (a) faktor jasmaniah, (b) faktor psikologis. Sedangkan faktor ekstern adalah faktor yang ada di luar individu, antara lain: (a) faktor keluarga, (b) faktor sekolah, dan (c) faktor masyarakat.

Hasil belajar yang dimaksud dalam penelitian ini adalah kemampuan atau tingkat penguasaan siswa terhadap materi pelajaran setelah mengikuti proses pembelajaran melalui pembelajaran kooperatif dengan tipe Numbered Heads Together (NHT).

\section{Media Kartu Indeks}

Media pembelajaran merupakan salah satu komponen pembelajaran yang mempunyai peranan penting dalam kegiatan belajar mengajar. Pemanfaatan media seharusnya merupakan bagian yang harus mendapat perhatian guru/fasilitator dalam setiap kegiatan pembelajaran. Media merupakan alat yang digunakan sebagai perantara untuk menyampaikan pesan dan dapat merangsang pikiran, perasaan dan kemajuan siswa sehingga dapat mendorong terjadinya proses belajar mengajar (Sabri, 2010).

Kartu indeks adalah kartu kecil yang berisi gambar, teks atau tanda simbol yang mengingatkan atau menuntun siswa kepada sesuatu yang berhubungan dengan gambar itu dan pada bagian belakang kartu tersebut terdapat pertanyaan yang berhubungan dengan isi gambar. Kartu indeks biasanya berukuran $8 \times 12 \mathrm{~cm}$ atau dapat disesuaikan dengan isi dari kartu tersebut. Kartu dibuat dengan menarik, sederhana dan terang/dapat dibaca sehingga mampu menyampaikan pesan yang terkandung di dalamnya dan mudah dipahami oleh siswa (Arsyad, 2007).

\section{METODE PENELITIAN}

\section{A. Jenis Penelitian, Waktu dan}

\section{Tempat Penelitian}

Penelitian ini merupakan jenis penelitian tindakan kelas (Classroom Action Research) dengan tahapan pelaksanaan meliputi perencanaan, 
pelaksanaan tindakan, observasi, refleksi,

perencanaan ulang dan

seterusnya.Penelitian ini dilaksanakan

dalam dua siklus, setiap siklus

dilaksanakan 2 kali pertemuan. Penelitian ini dilaksanakan pada bulan Juli sampai bulan September 2012 di SMP Negeri 3 Sabbangparu Kecamatan Sabbangparu Kabupaten Wajo.

\section{B. Subjek Penelitian}

Subjek penelitian adalah siswa kelas VIII SMP Negeri 3 Sabbangparu pada semester ganjil tahun ajaran 2012/2013 yang berjumlah 25 orang.

\section{Variabel Penelitian dan Definisi}

\section{Operasional Variabel}

1. VariabelPenelitian

Penelitian ini terdiri dari dua variabel, yaitu a. Model Pembelajaran Kooperatif Tipe Numbered Heads Together dengan media kartu indeks, b. Hasil belajar

2. Defenisi Operasional Variabel a. Model Pembelajaran Kooperatif Tipe Numbered Heads Together (NHT) dengan Media Kartu Indeks yaitu pembelajaran berbasis kelompok dengan Masingmasing siswa dalam kelompok diberi nomor untuk memudahkan

kinerjakelompok,menyusun materi,mempresentasikan dan mendapat tanggapan dari

kelompok lain. Media pembelajaran yang digunakan berupa potongan kartu yang berisikan pertanyaan ataupun pernyataan tentang materi yang dipelajari.

b. Hasil Belajar adalah nilai tes tingkat penguasaan siswa kelas VIII SMP Negeri 3 Sabbangparu Kabupaten Wajo terhadap mata pelajaran IPA Terpadu, yang diukur dengan memakai tes tertulis pada setiap akhir siklus.

\section{Prosedur Penelitian}

Prosedur Penelitian Tindakan Kelas (PTK) ini direncanakan 2 siklus yaitu siklus I dan siklus II. Antara siklus I dan siklus II merupakan rangakaian kegiatan yang saling berkaitan dalam arti pelaksanaan siklus II merupakan kelanjutan dari perbaikan siklus I. Gambaran umum yang dilakukan pada setiap siklus adalah: perencanaan, pelaksanaan, pengamatan, dan refleksi digambarkan sebagai berikut: 
Gambar 1. Skema Penelitian tindakan kelas (Iskandar, 2009)

\section{E. Sumber dan Jenis Data}

1. Sumber Data

Sumber data penelitian ini adalah siswa kelas VIII SMP Negeri 3 Sabbangparu Kabupaten Wajo.

2. Jenis Data

a. Data primer dari hasil observasi aktivitas belajar.

b. Data sekunder berupa hasil belajar.

\section{F. Teknik Pengumpulan Data}

1. Data tentang aktivitas pembelajaran selama tindakan dilakukan, diambil dengan menggunakan lembar observasi. Pada proses pengisian lembar observasi, semua indikator dari aktivitas yang diamati tercantum didalamnya. Jika siswa melakukan setiap aktivitas yang menjadi tolak ukur, maka ia akan memperoleh tanda checklist $(\checkmark)$ pada lembar observasi. Keadaan yang diobservasi adalah kegiatan siswa dalam peroses pembelajaran dengan penerapan model pembelajaran kooperatif tipe Numbered Heads Together (NHT).

2. Data mengenai hasil penerapan model pembelajaran kooperatif tipe Numbered Heads Together
(NHT) diperoleh dari tes hasil belajar setiap akhir siklus.

\section{G. Teknik Analisis Data}

Pengelolaan data pada penelitian ini dilakukan setelah terkumpulnya data, selanjutnya dianalisis secara kuantitatif dan kualitatif. Untuk analisis secara kuantitatif digunakan analisis deskriptif yaitu skor rata-rata yang diperoleh dari hasil tes tiap siklus yang bertujuan untuk mengetahui tingkat penguasaan materi melalui penggambaran karakteristik distribusi nilai pencapaian hasil belajar IPA Terpadu siswa yang diajar dengan menggunakan model pembelajaran kooperatif tipe Numbered Heads Together (NHT), pedoman pengkategorian menurut Arikunto (2005), sebagai berikut.

Tabel 1. Pengkategorian Tingkat Penguasaan Hasil Belajar IPA Terpadu

\begin{tabular}{cc}
\hline Interval nilai & Kualifikasi \\
\hline $\mathbf{8 0 - 1 0 0}$ & Sangat tinggi \\
$\mathbf{6 6 - 7 9}$ & Tinggi \\
$\mathbf{5 6 - 6 5}$ & Sedang \\
$\mathbf{4 0 - 5 5}$ & Rendah \\
\hline$\leq 39$ & Sangat rendah \\
\hline & \\
Untuk & menentukan ketuntasan
\end{tabular}

belajar siswa dengan melihat Tabel 1 Kategori Kriteria Ketuntasan Minimal (KKM) yang telah ditetapkan oleh sekolah.

Untuk analisis kualitatif dilakukan dengan melihat hasil observasi selama proses belajar mengajar dari tiap siklus. Dari aktifitas siswa dalam kelompok. 
Dengan menggunakan lembar observasi yang dilakukan oleh observator.

\section{HASIL PENELITIAN DAN PEMBAHASAN}

\section{A. Hasil Penelitian}

\section{Hasil Belajar Siklus I}

Berdasarkan "hasil" analisis deskriptif, skor tes hasil belajar IPA Terpadu siswa kelas VIII SMP Negeri 3 Sabbangparu Kabupaten Wajo setelah diterapkan penerapan model pembelajaran kooperatif tipe NHT dengan media kartu indeks selama siklus I, maka diperoleh deskripsi skor hasil belajar IPA Terpadu siswa yang ditunjukkan pada tabel 1 berikut :

Tabel 2. Nilai hasil belajar siswa kelas VIII.B SMP Negeri 3 Sabbangparu Kabupaten Wajo pada siklus I

\begin{tabular}{lc}
\hline \multicolumn{1}{c}{ Statistik } & Nilai Statistik \\
\hline Nilai rata-rata kelas & 64.93 \\
Nilai maksimum & 83.33 \\
Nilai mínimum & 30.00 \\
Rentang nilai & 53.33 \\
\hline
\end{tabular}

Berdasarkan hasil analisis

deskriptif pada tabel diatas nilai rata-rata hasil belajar Siswa kelas VIII SMP Negeri 3 Sabbangparu Kabupaten Wajo setelah proses belajar mengajar melalui penerapan Model Pembelajaran Kooperati tipe NHT dengan mendia Kartu Indeks yang dilaksanakan pada Siklus I adalah 64.93 dari skor ideal yang mungkin dicapai 100. Dari rentang skor yang diperoleh menunjukkan bahwa skor perolehan responden tersebar dari skor sangat rendah sampai skor sangat tinggi. Jika skor penguasaan siswa di atas dikelompokkan ke dalam lima kategori maka diperoleh distribusi frekuensi skor seperti ditunjukkan pada Tabel 4.3 berikut ini.

Tabel 3: Distribusi Frekuensi dan Persentase Skor Hasil Belajar Siswa Kelas VIII SMP Negeri 3 Sabbangparu Kabupaten Wajo pada siklus I

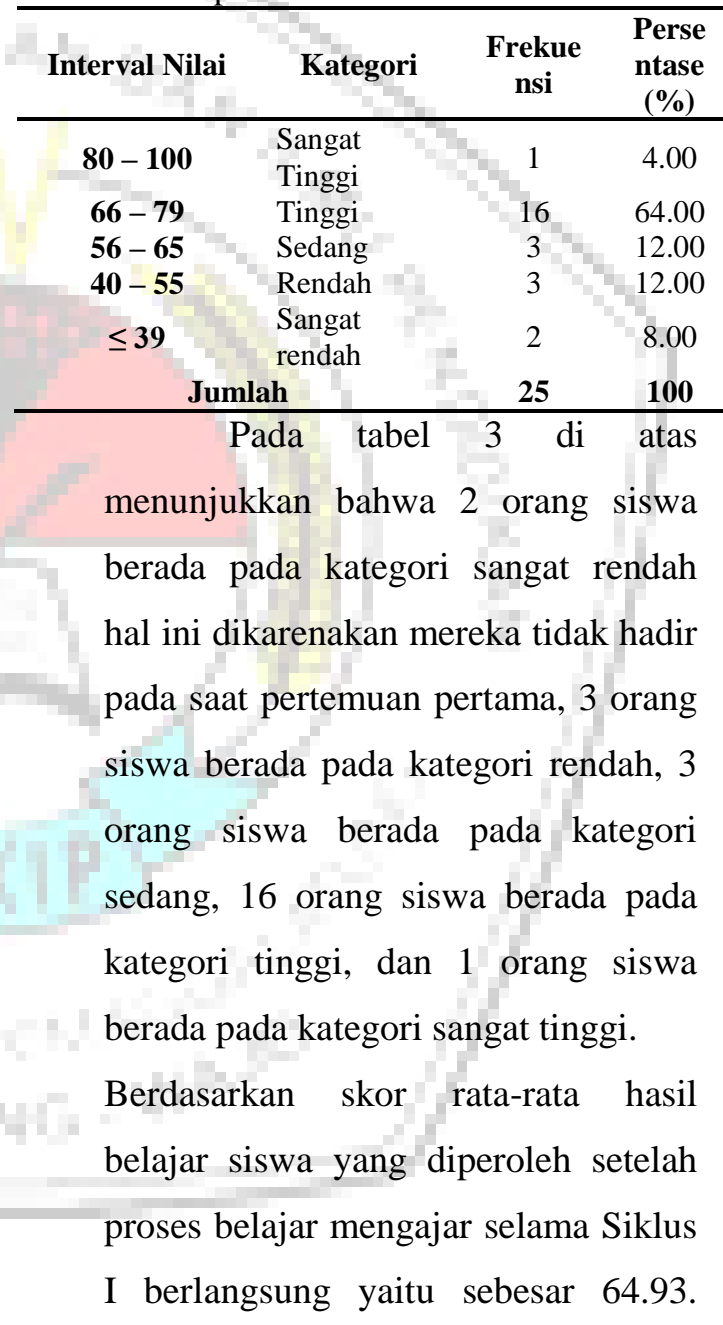

Setelah dikategorisasikan berdasarkan tabel 2 di atas, diketahui bahwa secara umum menunjukkan penguasaan siswa terhadap materi belum 
maksimal. Hal ini terlihat dari siswa yang mendapat nilai pada kategori sangat tinggi hanya 1 orang $(4.00 \%)$.

\section{Hasil Belajar Siklus II}

Berdasarkan hasil analisis deskriptif, skor tes hasil belajar IPA Terpadu siswa kelas VIII SMP Negeri 3 Sabbangparu Kabupaten Wajo setelah diterapkan penerapan model pembelajaran kooperatif tipe NHT dengan media kartu indeks selama siklus II, maka diperoleh deskripsi skor hasil belajar IPA Terpadu siswa yang ditunjukkan pada tabel 3 berikut :

Tabel 4 : Nilai hasil belajar siswa kelas VIII SMP Negeri 3 Sabbangparu Kabupaten Wajo pada siklus II

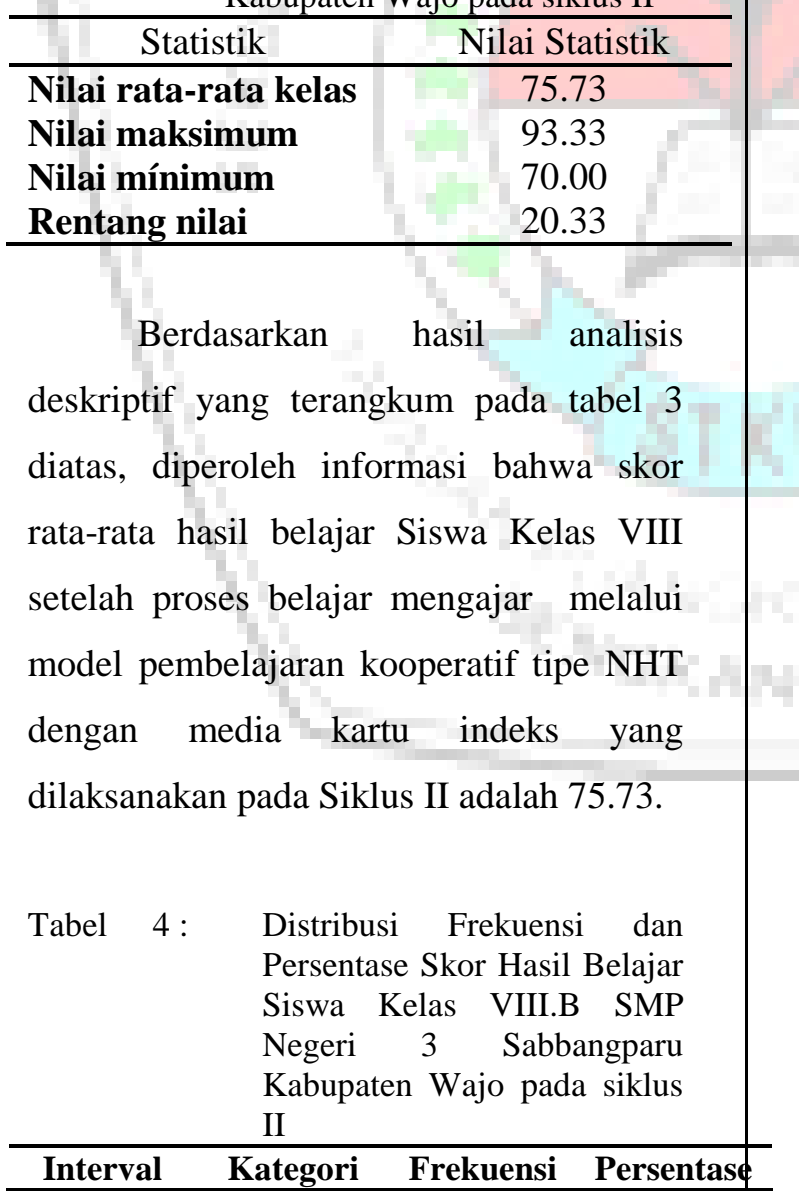

\begin{tabular}{clcc}
\hline Nilai & & & $(\%)$ \\
\hline $\mathbf{8 0}-\mathbf{1 0 0}$ & Sangat & 5 & 20 \\
& Tinggi & & \\
$\mathbf{6 6}-\mathbf{7 9}$ & Tinggi & 20 & 80 \\
$\mathbf{5 6}-\mathbf{6 5}$ & Sedang & 0 & 0 \\
$\mathbf{4 0 - 5 5}$ & Rendah & 0 & 0 \\
$\mathbf{5 3 9}$ & Sangat & 0 & 0 \\
& rendah & & \\
\multicolumn{2}{c}{ Jumlah } & $\mathbf{2 5}$ & $\mathbf{1 0 0}$ \\
\end{tabular}

Berdasarkan skor rata-rata hasil belajar siswa yang diperoleh setelah proses belajar mengajar selama Siklus II berlangsung yaitu sebesar 75.73. Setelah dikategorisasikan berdasarkan tabel di atas, diketahui bahwa tingkat penguasaan Siswa-Kelas VIII SMP Negeri 3 Sabbangparu berada pada kategori tinggi.

Hal tersebut menunjukkan bahwa jumlah siswa yang berada dalam kategori tuntas mengalami peningkatan yakni, 17 orang atau $68.00 \%$ pada Siklus I kemudian.

\section{B. Pembahasan}

Hasil tes setiap siklus menunjukkan adanya peningkatan hasi belajar siswa baik berdasarkan nilai ratarata maupun kategori. Sebelum pelaksanaan tindakan hasil belajar siswa secara umum dikategorikan rendah dengan nilai rata-rata 62.93. Hal ini mungkin dikarenakan penggunaan model pembelajaran yang masih bersifat searah dan tidak menggunakan media pembelajaran. Namum setelah diadakan penelitian pada siklusIdan Siklus II terjadi peningkatan dengan menggunakan model 
pembelajaran Kooperatif tipe NHT yang dipadukan dengan media kartu indeks pada pokok bahasan sistem peredaran darah.

Penguasaan siswa terhadap konsep sistem peredaran darah setelah menggunakan model pembelajaran kooperatif tipe NHT dengan media kartu indeks, menunjukkan terjadinya peningkatan rata-rata hasil belajar IPA Terpadu siswa kelas VIII SMP Negeri 3 Sabbangparu Kabupaten Wajo dari siklus I ke siklus II, yaitu 64.93 menjadi 75.73 atau meningkat sebesar 10.80 . Peningkatan persentase hasil belajar pada siklus I dan siklus II apabila dikelompokkan kedalam lima katergori yang divisualisasikan dalam pada bentuk histogram berikut :

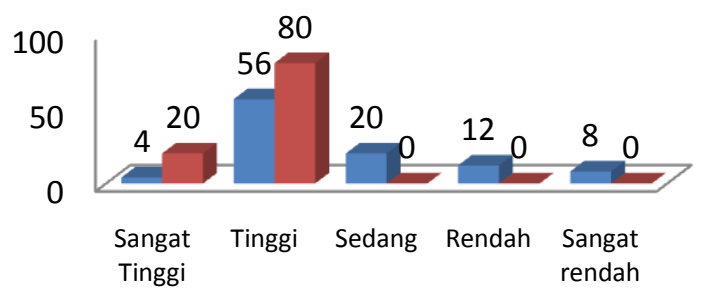

Siklus I Siklus II

Gambar 2. Grafik perbandingan persentase kategori hasil belajar

Berdasarkan pengamatan antara hasil analisis data secara kualitatif dan data secara kuantitatif, maka terlihat bahwa penerapan model pembelajaran kooperatif tipe NHT dengan media kartu indeks dapat meningkatkan hasil belajar IPA Terpadu siswa kelas VIII. B SMP Negeri 3 Sabbangparu Kabupaten Wajo.
Selain hasil belajar yang meningkat, aktivitas siswa dalam proses belajar mengajar juga meningkat. Ini sesuai yang dikatakan Sardiman (2001) bahwa "belajar berarti usaha mengubah tingkah laku. Jadi, belajar akan membawa suatu perubahan pada individu-individu yang belajar. Perubahan itu tidak hanya berkaitan dengan penambahan ilmu pengetahuan tetapi juga berbentuk kecakapan, keterampilan, sikap, minta dan penyesuaian diri.

Meningkatnya hasil belajar dari siklus I ke siklus II disebabkan karena penerapan model pembelajaran kooperatif tipe NHT dengan media kartu indeks dalam proses pembelajaran dapat membantu siswa memahami konsep IPA Terpadu secara teoritis. Dengan penerapan model pembelajaran ini siswa tidak pasif dalam menerima materi dari guru tetapi mereka secara aktif membangun sendiri pemahaman mereka.

Peneliti menyadari bahwa strategi pembelajaran yang diterapkan guru adalah salah satu faktor yang menentukan keberhasilan dalam prestasi belajar mengajar. Pemilihan strategi pembelajaran yang tidak tepat dapat menurunkan motivasi dan minta belajar belajar siswa sehingga tujuan pembelajaran tidak tercapai secara optimal. Dengan model pembelajaran kooperatif tipe NHT yang yang dipadukan media pembelajaran visual berupa kartu indeks pada anak didik 
dapat membantu ingatan dan mengecek pemahaman siswa terhadap isi pembelajaran, sehingga dapat tercapai tujuan pembelajaran,hal ini kurang diperhatikan pada pembelajaran konvensional.

\section{KESIMPULAN}

Berdasarkan observasi dan analisis data, dan pembahasan dapat disimpulkan bahwa : "Penerapan model pembelajaran kooperatif tipe NHT dengan menggunakan kartu indeks dapat meningkatkan hasil belajar siswa pada konsep sistem peredaran darah siswa kelas VIII SMP Negeri 3 Sabbangparu Kabupaten Wajo".

\section{DAFTAR PUSTAKA}

Abdurrahman. 1994. Pengelolaan Pengajaran. Ujung Pandang: C.V. Bintang Selatan

Arikunto, Suharsimi. 2005. DasarDasar Evaluasi Pendidikan. Jakarta: Bumi Aksara.

Arsyad. 2007. Media Pembelajaran. Jakarta: PT. Raja Grafindo Persada.

Ibrahim, M, Fida Rachmadiarti, Mohammad Nur dan Ismono. 2000. Pembelajaran Kooperatif. Surabaya: University Press.

Ismail, I. 2006. Pedoman Penulisan Skripsi.Jakarta: Civil Society Foundation

Iskandar. 2009. Penelitian Tindakan Kelas. Ciputat: Gaung Persada (GP) Press.
Kiranawati. 2007. Numbered Heads Together.

(Online),(http://www.Guru PKn Belajar Menulis.htm,diakses 10 Juni 2012).

Lie, A. 2008. Cooperative Learning Mempraktekkan Cooperative Learningdi Ruang-Ruang Kelas. Jakarta: PT. Gramedia.

Nurhayati dan Sappe. 2004. Strategi Belajar dan Pembelajaran. Makassar: Jurusan IPA Terpadu FMIPA UNM.

Nurwahyuni. 2006. Meningkatkan Prestasi Belajar Siswa Kelas $\mathrm{XI}_{\text {IA-1 }}$ SMA Muhammadiyah Kendari Melalui Model PembelajaranKooperatifTipe NHT. (Online), (http://ipotes.wordpress.com/200 8/05/10/metode-pembelajarankooperatif/,diakses 10 Juni 2012).

Sabri, A. 2010. Strategi Belajar Mengajar \& Micro Teaching. Ciputat: PT. Ciputat Press.

Sadiman. 2008. Media Pendidikan. PT. Raja Grafindo Persada. Jakarta.

Sardiman, A.M. 2001. Belajar dan Pembelajaran. FIP UNM: Makassar.

Sudjana, dan Rivai. 1991. Media Pembelajaran. Bandung: CV. Sinar Baru Algesindo.

Sudijono, A.2001. Pengantar Evaluasi Pendidikan. Jakarta: PT. RajaGrafindo Persada.

Trianto. 2007. Model-Model Pembelajaran Inovatif Berorientasi Konstruktivistik. Jakarta: Prestasi Pustaka 